Short communication

\title{
Rice false smut [Ustilaginoidea virens (Cooke) Takah.] in Paraguay
}

\section{Lidia Quintana $^{1 *}$, Susana Gutiérrez ${ }^{2}$, Marco Maidana ${ }^{1}$ and Karina Morinigo ${ }^{1}$}

${ }^{1}$ Facultad de Ciencias Agropecuarias y Forestales, Universidad Nacional de Itapúa, Encarnación, Paraguay

${ }^{2}$ Facultad de Ciencias Agrarias, Universidad Nacional del Nordeste, Corrientes, Argentina

*Corresponding Author: lviedmaq@gmail.com

[Accepted: 28 December 2016]

[Cite as: Quintana L, Gutiérrez S, Maidana M \& Morinigo K (2016) Rice false smut [Ustilaginoidea virens (Cooke) Takah.] in Paraguay. Tropical Plant Research 3(3): 704-705]

False smut of rice, caused by Ustilaginoidea virens (Cooke) Takah., is a common disease in rice panicles. Disease was first reported in India (1878) and was considered as a secondary disease due to their sporadic occurrence (Ladhalakshmi et al. 2012). In the 2014-2015 growing season disease survey was conducted in different rice producting areas of the country. Rice plants of IRGA 424 cultivar were observed, whose panicles had grains replaced by globose yellowish green masses of spores. These symptoms were visible after crop flowering, when the fungus transforms individual grains of the panicle into globose green-yellow mass that subsequently acquire greyish-black color.

In the national bibliography no history published about this disease was found, thus the objective of this study was to determine the etiology of this new disease in Paraguay. One hundred and twenty panicles taken from fields with symptoms and signs of false smut were collected in the districts of General Delgado, General Artigas and Coronel Bogado (Itapúa Department), districts of Santa Maria, San Juan Bautista and San Juan de Ñeembucú (Misiones Department). The symptoms and signs were observed with naked eye and under an stereomicroscope (40x). Reproductive structures (spores) from the affected panicles were examined and measured using a compound microscope (400x). Subsequently, the fungus spores were seeded on potato dextrose agar for observation of the colonies.

The false smut was detected in green rice plants at ripening stage in IRGA 424 cultivar, grown in the departments of Itapúa and Misiones. The disease incidence in panicles was 40\%, with at least 2-3 galls per symptomatic panicles.

This disease has been described in all rice producing countries in the world such as India, Australia, Pakistan, the United States, Mexico, the Philippines and Peru (Ou 1985, Webster \& Gunnel 1992). In Argentina, the disease was reported by Gutiérrez et al. (2000). Its occurrence is related to soils with high fertilization, rainy periods with humidity higher than $90 \%$, especially during the crop flowering stage (Ahonshi et al. 2000). These weather conditions during 2015 growing season, coincided with the El Niño phenomenon.

The symptoms observed were similar with those described by (Padwick 1950, Ou 1985, Webster and Gunnel 1992). The symptoms are visible only after flowering when the fungus transforms the individual grains of the panicle into globose structures or yellowed carbonaceous masses. These masses are dusty representing more than twice the diameter of normal grain and at early development are yellow and then acquire dark green or almost black color, and explode releasing the spores of the fungal causal agent (Fig. 1).

Isolation and identification of the causal agent: Grain samples infected with false smut were collected from different monitores localities. Infected kernels were washed with tap water to remove dust particles and surface disinfestated with sodium hypochlorite solution (2.5\%) for 1-2 minutes, dried and then transferred to potatodextrose-agar culture medium and incubated at $25-28^{\circ} \mathrm{C}$ for $7-10$ days.

Morphometric characteristics of the pathogen found in the panicle were similar to those described by several authors (Mew \& Misra 1994, Mulder \& Holliday 1985, Ou 1985, Webster \& Gunnel 1992). Chlamydospores formed in the masses of spores are spherical to elliptical, warty, of olive color, and 3 to $5 \times 4$ to $6 \mu \mathrm{m}$. Colonies on PDA developed in approximately 14-15 days. The causal agent of rice false smut was identified as Ustilaginoidea virens (Cooke) Tak. This is the first report of rice false smut in Paraguay. 

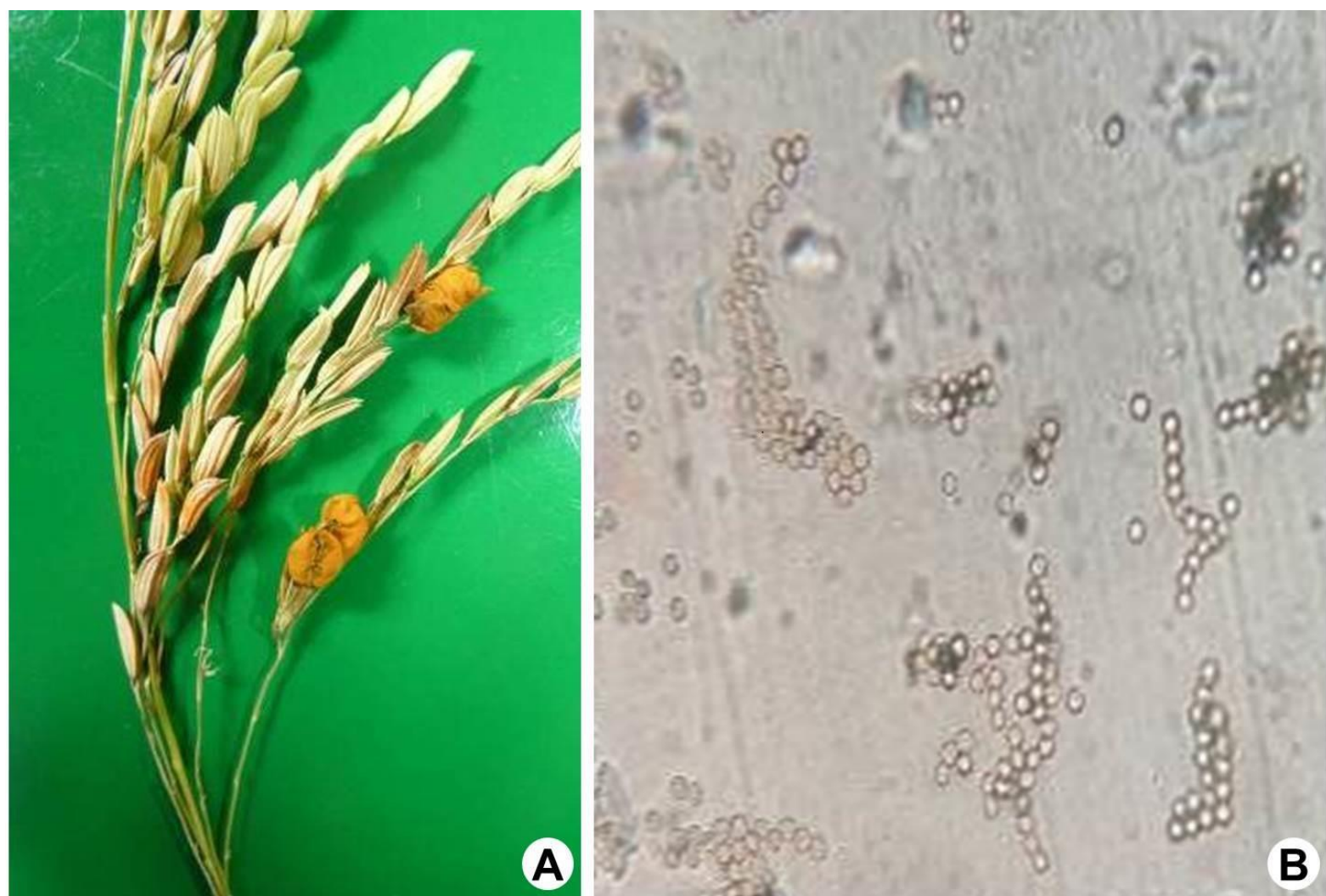

Figure 1. Symptoms and signs of false smut caused by Ustilaginoidea virens (Cooke) Takah. in rice panicle: A, Spore galls on panicle; B, Chlamydospores.

\section{REFERENCES}

Ahonshi MO, Adeoti ID, Erinkle TA, Alegrejo BN \& Singh AA (2000) Effect of variety and sowing date of false smut incidence in upland rice in Edo State. Nigeria IRRI Notes 25: pp. 14

Gutiérrez de Arriola SA, Cúndom MA \& Mazzanti de Castañon MA (2000) Caracterización del Falso Carbón (Ustilaginoidea virens). Enfermedad de reciente aparición, en cultivos de arroz de Argentina. En: Reunión de Comunicaciones Científicas y Tecnológicas, SGCYT, UNNE.

Ladhalakshmi D, Laha GS, Singh R, Karthikeyan A, Mangrauthia SK, Sundaram RM, Thukkaiyannan P \& Viraktamath BC (2012) Isolation and characterization of Ustilaginoidea virens and survey of false smut disease of rice in India. Phytopara 40: 171-176.

Mew TW \& Misra JK (eds) (1994) A Manual of rice seed testing. Philippines IRRI, Los Baños, 113p.

Mulder JL \& Holliday P (1985) Ustilaginoidea virens. Descriptions of Pathogenic Fungi and Bacteria. CAB International, Wallingford, 30: $296 \mathrm{p}$.

Ou SH (1985) Rice Diseases. $2^{\text {nd }}$ Edition. Commonwealth Mycological Institute, U.K., 385 p.

Padwick GW (1950) Manual of rice diseases. Commonwealth Mycological Institute, Kew, 198 pp.

Webster RK \& Gunnell PS (1992) Compendium of rice diseases. St. Paul. American Phytopalogical Society. 